\title{
Sexuality and the Development Industry
}

\section{Sexuality and the Development Industry Workshop}

How do development interventions impact on people's sexualities? And how can development agencies move towards more constructive engagement with sexuality? These were the topics of discussion in International Development Studies, University of Sussex, Brighton, UK from 3-5 April for more than 70 workshop participants from a range of activist groups, NGOs, universities, government bodies and donor organizations worldwide.

Many of the articles are based on these presentations; for more go to http://www. ids.ac.uk/go/about-ids/news-and-commentary/april-2008-news/sexuality-and-thedevelopment-industry-workshop to listen to the presentations as well as tune into Podcasts from the workshop on Sexuality and the Development Industry - An interview with keynote speaker Sonja Corrêa and Heteronormativity Explained - An interview with Amy Lind.

The Workshop Report can be viewed at http://www.ids.ac.uk/go/sexualityand development. 